\title{
Streams and River-Beds
}

James' Stream of Thought in Wittgenstein's Manuscripts 165 and 129

\section{Anna Bocompagni}

\section{(2) OpenEdition}

\section{Journals}

Electronic version

URL: http://journals.openedition.org/ejpap/718

DOI: $10.4000 /$ ejpap.718

ISSN: 2036-4091

Publisher

Associazione Pragma

\section{Electronic reference}

Anna Bocompagni, «Streams and River-Beds », European Journal of Pragmatism and American

Philosophy [Online], IV-2 | 2012, Online since 24 December 2012, connection on 20 April 2019. URL

http://journals.openedition.org/ejpap/718 ; DOI : 10.4000/ejpap.718

This text was automatically generated on 20 April 2019.

\section{(c) $($ ) $\odot$ (8)}

Author retains copyright and grants the European Journal of Pragmatism and American Philosophy right of first publication with the work simultaneously licensed under a Creative Commons Attribution-

NonCommercial-NoDerivatives 4.0 International License. 


\section{Streams and River-Beds}

James' Stream of Thought in Wittgenstein's Manuscripts 165 and 129

\section{Anna Bocompagni}

\section{Introduction}

1 Ludwig Wittgenstein's interest in the writings of William James characterizes the whole of his philosophical work. We know from a letter to Bertrand Russell that as early as 1912 he was reading The Varieties of Religious Experience, a book that gave rise to his attraction for mysticism, ${ }^{1}$ and that he later warmly recommended to his friend Maurice Drury. ${ }^{2}$ After his return to philosophy, in his notebooks and typescripts he refers to James and particularly to The Principles of Psychology (PP) ${ }^{3}$ from the beginning of the Thirties to the end of his life. ${ }^{4}$ Furthermore, we know that he even thought of using it as a textbook for his lessons in Cambridge, though according to some critics more as a set of examples of the mistakes of psychologists than as a handbook in the usual sense. ${ }^{5}$ Wittgenstein's interest in James' psychology, far from diminishing, even increased in the last years of his life, and was at its greatest after the Second World War: the notes from his 1946-47 lectures collected by his students Peter Geach, Kanti Shah and A. C. Jackson ${ }^{6}$ are full of explicit and implicit references to James, as well as the RPP (1946-48) and generally the manuscripts of those years; besides, one should not forget the influence of James' thought on some relevant, though often neglected, concepts of the later Wittgenstein, such as those of patterns of life, the indeterminacy of psychological concepts, the connection between emotions and the expression of emotions. ${ }^{7}$

2 In spite of some early positive comments, notably not belonging to the Wittgensteinian tradition, ${ }^{8}$ Wittgenstein's attitude towards James and towards the PP has often been described by Wittgenstein's scholars as merely critical and negative. Peter Hacker, for example, mentions James may times in his extensive commentary on the PI, but usually as a negative counterpart of Wittgenstein's ideas, sometimes identifying him with one of the invisible interlocutors against which the philosopher battles in his remarks. ${ }^{9}$ Regarding the stream of thought, Hacker depicts it as "philosophical confusion" and even 
bluntly affirms that it is "largely a meaningless babble." ${ }^{10}$ But, as more recently stated by some other commentators, ${ }^{11}$ Wittgenstein's attitude should be better described as twofold: although he criticized James in many respects, he also appreciated James' masterpiece, particularly for its richness of examples, its freshness, depth and also for the "humanity" of its author. ${ }^{12}$

The PP chapter on the stream of thought is one of the main objects of concern for Wittgenstein. It is here that we find some examples that he often cited and criticized, such as that of the "and-feeling," the "if-feeling" and the like (PP: I, 245; cf. PI: part II, 155, RPP: I, §§ 331, 334), the recalling of a forgotten name or meaning (PP: I, 251; RPP: I, §§ 174, 180), the feeling connected to the intention of saying something (PP: I, 253; RPP: II, §§ 242-3, PI: part I, §§591, 633, part II, 155, 182), and the case of Mr. Ballard as showing the possibility of there being thought without language (PP: I, 266, PI, part I: § 342).

Strangely enough, James' image of the stream has only rarely ${ }^{13}$ been associated with Wittgenstein's use of the metaphor of the flux or of the river. The latter uses this image in various periods and with various meanings. During the phenomenological years of the PR, he speaks about the flux of experiences and of the vagueness of immediate experience: here the theme is connected to the question whether it is possible or not to have a language of immediate experience. In these years Wittgenstein sometimes holds that it is only in the flux of experience that any sentence can be verified, though it is constitutively impossible for language to directly denote the elements of the flux. ${ }^{14}$ The reading of James' PP may hold some responsibility for the emergence of this set of problems. When Wittgenstein's interest turns from the phenomenological language to the ordinary language, the image of the flux turns from the flux of experiences to the flux of life and discourse. Again, it is probably James that Wittgenstein has in mind when he points out that the meaning of any expression is not to be found in the flux of experiences but in the context of the discourse and, more generally, in the context of life, with its linguistic games and its background of know-how and culture. ${ }^{15}$ So, as Steiner (2012) elegantly surmises, what enables our understanding of psychological concepts and phenomena is not a mental immanence, but an anthropological-normative immanence: a logicalgrammatical context together with an anthropological background. ${ }^{16}$

What is still missing in the secondary literature, as far as I know, is a comparison between James' stream of thought and Wittgenstein's river-bed of thoughts, which he describes in OC with the aim of distinguishing between logical and empirical propositions. In discussing the river-bed of thoughts Wittgenstein does not explicitly address James. But the choice of the image and the words used to describe it can and do suggest such a connection. Is it possible to find in the Nachlass details or evidence pointing in this direction? Can Wittgenstein's river-bed be read - among other things - as a direct comment on James' stream? As we shall see, the comparison and this conclusion are legitimated by two remarks contained in Manuscripts 165 and 129. ${ }^{17}$

\section{The Nachlass}

6 The name "James" appears 90 times in Wittgenstein's Nachlass, from $19322^{18}$ to $1950-51 .{ }^{19}$ In particular, considering both the English expression "stream of thought" and its equivalent in German "Gedankenstrom," we can find four contexts in which Wittgenstein makes use of James' metaphor, some of which recur more than once. ${ }^{20}$ 
7 The first entry is in Item 120 (1937-38), a manuscript which is well-known because it contains three drafts of the future preface of the PI. On February, 27th 1938 Wittgenstein wrote a dozen pages in the manuscript, and it is here that we find the word "Gedankenstrom" in the context of a discussion concerning if and when a man can be said to be wrong when speaking about a pain that he is feeling. In the case of something suspending or changing the direction of the man's attention, Wittgenstein says, "the stream of thought is interrupted, and we can only guess how it could have proceeded." 21 Here, it seems, the meaning of Gedankenstrom is not in question: Wittgenstein is using it as a unproblematic concept, within the discussion of a peculiar language game. I shall call this use of James' expression "the unproblematic stream."

8 The second occurrence is in Item 124, a manuscript volume containing remarks mostly from 1944. After considering the problem of the relation between expectation and fulfillment, and stressing the importance of the circumstances in which an expectation takes place, Wittgenstein writes: "Here one could speak of the stream of thought, of which James talks, and point out that, when a well-known name is mentioned to me, my thoughts pour forth into a series of canals, and they continue to run in them, and that the meaning of the name is revealed in these streams." 22 In the following lines there is a critique to James: "He should tell us what happens, while he only tells us what must happen - Wittgenstein writes -. He wants to communicate an empirical fact, but he slips and makes a metaphysical remark." I shall call this occurrence 'the slippery stream.'

9 The third entry can be found in Item 165, a pocket notebook with remarks dating back, again, mostly to 1944 and often mentioned in relation to the debate on following a rule and on the private language argument. Many of these remarks are crossed through by vertical or diagonal lines, and this is also the case of the passage we are going to cite. Since this remark will appear again, with some variations, in a slightly later and more accurate manuscript with no deletions, it is also worth working on this version, which is very explicit about James' 'mistake.' In discussing the relation between expectation and fulfillment, intention and meaning, Wittgenstein proposes an example:

I'm waiting for two people A and B. I say: "When will he come!" Someone asks me: "Who do you mean?" I say, "I thought about A." And these very words have built a bridge. Or he asks "Who do you mean?" I say, "I thought about..." a poem in which there is this sentence. I make these connections among what I say in the course of my thoughts and actions. (This remark is in relation with what W. James calls "the stream of thought." The mistake in his picture is that a priori and a posteriori grammatical and experiential are not distinguished. So he speaks about the continuity of the stream of thought and he compares it with that of spaces, not with that of a sort of jet of water). ${ }^{23}$

10 The theme of expectation and fulfillment is often present in Wittgenstein's writings; the example with the expression "When will he come"! - without the explicit reference to James' stream of thought - recurs also in typescripts $211,212,213$ of the beginning of the Thirties, in various manuscripts of the Fourties and in Part I of the PI (§ 544).

11 The later manuscript which I mentioned is Item 129, a volume of the second half of 1944. Correcting some previous misprints, Wittgenstein writes:

(I believe, that this remark is in relation with what W. James calls "the stream of thought." Even though he certainly does not distinguish a priori and a posteriori, empirical and grammatical propositions). ${ }^{24}$

12 Again and with more clarity, Wittgenstein points out - although now without speaking of a mistake - that James does not distinguish between a priori and a posteriori; and in this 
case he speaks of grammatical and empirical propositions. I shall call this occurrence, in the two formulations of MS 165 and 129, "the stream with no banks."

In the same MS 129, only a few pages after what we have just read, we find the next entry. "One could say - writes Wittgenstein -: I would not have an impression of the room as a whole, if I could not let my glance wonder here and there and myself move around freely. (Stream of thought.) James." ${ }^{25}$ And he continues: "But how does it show that I have an impression of it as a whole? In the naturalness with which I find my way in it; in the absence of querying, doubting and surprise; in the fact that within its walls innumerable activities are encompassed; and in the fact that I sum up all this as 'my room' in the speech." Here the stream of thought seems to correspond to a mentalist way of conceiving what it is to know a certain meaning, a conception that Wittgenstein contrasts by underlying the importance of actions and know-how. This last remark on the stream of thought is repeated in Typescript 228 (1945-46), with no variations, and again, with minor variations, in Typescript 233a, which was published as Zettel (in the published edition we find it as § 203). I shall call this stream "the impressionist stream."

Let us sum up. The first occurrence of the term seems, as we have seen, unproblematic: Wittgenstein simply uses it in the context of the discussion of the meaning of internal states such as pain and of the criterion of attributing truth or falsity to a man's assertions about his state. If meaning is to be found in the stream of thought, and the justification for a true assertion too, then the interruption of the stream of thought may cause problems in the identification of meaning and truth conditions. But is meaning to be found in the stream of thought? This question, which is probably already implicitly present in the "unproblematic stream," is more explicitly addressed in what I have called the "slippery" and the "impressionist" streams. In the first case, meaning is seen as the streams and currents in which thought pours when a well-known name is mentioned. But this characterization fails in its attempt to catch the empirical, experiential facts about meaning, and becomes metaphysical. In the case of "the impressionist stream," Wittgenstein underlines the importance of some physical and active elements in the determination of meaning (here, the meaning of a room, identified with the impression of the room as a whole). Instead of accepting a private approach which stresses the role of sensory impressions, Wittgenstein directs the attention towards the practical, behavioural and linguistic elements in which the possession of the meaning shows itself.

The "slippery" and the "impressionist" conceptions of the stream as the inner place of meaning (and, maybe, also the seemingly unproblematic first version) are both criticized by Wittgenstein for their commitment to a psychologistic, internalist idea of the mind and of meaning itself. The critique is addressed not only to James, ${ }^{26}$ but also to Wittgenstein's own phenomenological phase: the argument against a private language can be read as an implicit critique of the attempt to find truth conditions in the flux of experiences or of thought, as this flux is intrinsically private and can rely on no public criteria of assertibility or justification. ${ }^{27} \mathrm{~A}$ private language is impossible because, if it is language, then it is not private: ${ }^{28}$ this is part of the grammar of the word "language." Thus, when James tries to explain meaning by referring to the stream thought, in Wittgenstein's view he misses the point. It is true that language and meaning belong to a flux, but this is not the flux of thought: it is the flux of discourse and of life. ${ }^{29}$ So, its depth and richness notwithstanding, James' psychology - in Wittgenstein's view - remains anchored to an introspective method which leads us astray (PI: §§ 411-14) and contributes to the construction of the image of an internal realm, which is not so distant from the 
classic Cartesian image. Two aspects must be, anyway, underlined: that James himself tried to abandon the Cartesian concept of consciousness (Myers 1986: 61), and that his appeal to experimental techniques and physiological theories aimed at a methodological pluralism which mitigated the importance of introspection. Wittgenstein evidently thought that it was not enough, and that James' perspective was an example of a discipline torn between "experimental methods and conceptual confusion," as he famously stated in the final paragraph of the PI. ${ }^{30}$

The remaining two occurrences of the "stream with no banks" are the remarks to which I would like to dedicate the next section of this paper, for two reasons: because they allow us to inquire further into one of Wittgenstein's critiques towards James, which has not yet been analyzed in depth; and because it can be fruitfully connected to Wittgenstein's own image of the river-bed of thoughts.

\section{MS 165 and 129 as an Anticipation of the Metaphor of On Certainty}

17 Let us take a closer look at these two remarks. MS 165 attributes a mistake to James: that of not distinguishing between a priori, or grammatical, and a posteriori, or empirical. Mixing together these two aspects, Wittgenstein explains, James is not actually speaking of a stream or of a jet of water; it would be more appropriate to say that he is speaking of spaces and of the continuity of spaces. It is not easy to understand why it should be so. Perhaps, we can argue, in the case of spaces it is correct not to distinguish between something fixed and something variable: spaces have no banks, while streams do have banks and stream-beds, they are defined by something that does not change - or at least that does not change as rapidly as its content. In passing from MS 165 to MS 129, which has the character of a more definite work, this reference to the continuity of spaces is eliminated and the accusation is mitigated (there are no "mistakes" anymore), but, again, Wittgenstein underlines the fact that James calls thought a "stream," in spite of his not distinguishing a priori and a posteriori. In other words, given his characterization of thought, James should not have used the picture of a stream; conversely, if this can be said to be a good image of thought, then James' description of thought is fallacious.

The topic of the distinction between what is empirical (experiential, phenomenal) and what is grammatical (conceptual, logical) is extensively treated Wittgenstein's lectures of the post-war years and in RPP, besides constituting one of the main themes of OC. In Jackson's notes of the lectures we can read, for example:

Now consider the suggestion: You've already thought the meaning before you speak (James). Is this a psychological statement? If so, how many men does it apply to? Or does it apply each time? If it's a psychological statement it's an hypothesis: but James wishes to say something essential about thinking. ${ }^{31}$

Where is, then, the problem with James' stream: in the description of thought, or in the image? Evidently, for Wittgenstein, in the description. Indeed, it is exactly the image of the stream that Wittgenstein himself will adopt, a few years later, in his own characterization of thought. If read in this light, propositions 95 to 99 of OC not only give a metaphorical description of thought and of the relation between the Weltbild (picture of the world) and thought; but also constitute an implicit critique of James' use of that metaphor. Or, better said, they contribute to an implicit praise of James' image, and an implicit critique of James' interpretation of his image: 
95. The propositions describing this world-picture might be part of a kind of mythology. And their role is like that of rules of a game; and the game can be learned purely practically, without learning any explicit rules.

96. It might be imagined that some propositions, of the form of empirical propositions, were hardened and functioned as channels for such empirical propositions as were not hardened but fluid; and that this relation altered with time, in that fluid propositions hardened, and hard ones became fluid.

97. The mythology may change back into a state of flux, the river-bed of thoughts may shift. But I distinguish between the movement of the waters on the river-bed and the shift of the bed itself; though there is not a sharp division of the one from the other.

98. But if someone were to say "So logic too is an empirical science" he would be wrong. Yet this is right: the same proposition may get treated at one time as something to test by experience, at another as a rule of testing.

99. And the bank of that river consists partly of hard rock, subject to no alteration or only to an imperceptible one, partly of sand, which now in one place now in another gets washed away, or deposited.

20

the relation between the propition of the world-picture and empirical propositions. The former are those which allow the latter to work. Any empirical proposition is grounded in the common sense certainties which shape our Weltbild, the way we see the world, the way we are minded, the picture or the "mythology" which, so to speak, keeps everything together. Even when they look like empirical propositions ${ }^{32}$ - "Here is one hand" is the classical example ${ }^{33}$ - Weltbild propositions are different in kind; it is meaningless to ask whether they are true or false, as they form the background against which truth and falsity themselves are defined. They are the hinges that must stay put, in order for the door to move.

21

literature on Wittgenstein's hinge propositions is vast and constantly increasing. For its clarity and conciseness, it is useful to cite Danièle Moyal-Sharrock's comment (2007: 72), according to which hinge propositions are:

- indubitable: doubt and mistake are logically meaningless;

- foundational: they do not result from justification;

- nonempirical: they are not derived from the senses;

- grammatical: they are rules of grammar;

- ineffable: they cannot be said;

- in action: they can only show themselves in what we say and do.

, says Moyal-Sharrock, even when they have an apparent propositional nature, constitute non-propositional certainties, and are akinto instincts, ways of acting, attitudes. Logic itself, since it is hinged on these certainties, belongs to the reign of instinct and not to that of reason, and Wittgenstein could be considered the supporter of a logical pragmatism which asserts the enacted nature of hinge certainties. ${ }^{34}$

Logical propositions are not about facts in the world (notice how near this sounds to the Tractatus). They work on the level of rules and normativity; it is the level of certainty, which is categorically distinct from that of knowledge..$^{35}$ Common sense propositions like the Moorean "Here is one hand" or "The earth existed for a long time before my birth," except when they are said in peculiar contexts and circumstances, do not express a genuine knowledge. In Moore's (and James') ${ }^{36}$ opinion, we know these propositions for certain, even if we cannot prove them or give a ground for them. Wittgenstein denies that we have an epistemic relation with what these propositions assert. The reason why we cannot give a ground for these sorts of belief, is that the certainty which characterizes 
them is itself a ground, and it shows itself in the ordinary "going without saying" of these certainties. In everyday contexts, hinges work tacitly, they do not require to be formulated; according to Moyal-Sharrock (2007: $94 \mathrm{ff}$.), they even require not to be formulated, not to be said, because once said they would not go without saying. As Coliva (2010: 151, 177) partially corrects, the only possibility for a hinge proposition to be meaningfully uttered, is when it is used not in a descriptive but in a communicative and/ or normative manner.

In Wittgenstein's metaphor, there is not a sharp division between the movements of the waters in the river-bed and the movement of the river-bed itself; moreover, the banks of the river are stratified, consisting partly of rock, partly of sand. This is not to be interpreted as meaning that, at bottom, no distinction can be made. ${ }^{37}$ The distinction is at the same time categorical and not sharp, because one and the same proposition can work now as empirical and now as logical, but never as both. The shift from one to the other uses may sometimes be due to slow changes in the Weltbild, as it is clear for example in the case of Wittgenstein's own certainty that man has never gone and never will be able to go to the moon. ${ }^{38}$ But the change of the Weltbild (river-bed) does not occur at the same empirical level as the change of what the Weltbild frames (waters).

Although Wittgenstein's interlocutor in $O C$ is primarily Moore, this is evidently the same kind of objection that in the Manuscript notes he addressed to James. Besides, Wittgenstein's discussion of the Weltbild is particularly significant in the context of psychological concepts and propositions, the "objectivity" of which, as Egidi (1995: 176) puts it, "is not achieved by reference to objects, of both internal and external nature, but depends on whether those sentences obey the system of rules of which they are part," which, in turn, imply a complex of "pragmatic criteria of significance." Wittgenstein's discussion of psychology in his later years, then, in its connection to the theme of the Weltbild and to the distinction between grammatical and empirical, can be read also as an implicit critique of his phenomenological years and of the jamesian strand which can be identified in his attempts to catch the flux of experiences. This is another reason which contributes to the plausibility of reading the image of the river-bed as a sort of correction of James' image of the stream.

\section{Is Wittgenstein's Critique Justified?}

In order to ascertain whether Wittgenstein's critique of James is justified, we now need to turn to the PP. In the chapter on the stream of thought, James, as is well-known, characterizes it through five features (PP: I, 225):

- Every thought tends to be a part of a personal consciousness;

- Within each personal consciousness thought is always changing;

- Within each personal consciousness thought is sensibly continuous;

- It always appears to deal with objects independent of itself;

- It is interested in some parts of these objects to the exclusion of others, and welcomes or rejects all the while.

It is in particular in the second and third characters, change and continuity, that James' stream differs from Wittgenstein's. Change is what may suggest, if ever, the comparison between his stream and Heraclitus' river, and indeed James is reminiscent of Heraclitus when he writes that "no state once gone can recur and be identical with what it was before" (PP: I, 230), that "there is no proof that the same bodily sensation is ever got by us 
twice" (231), and of course when he affirms that "of the river of elementary feeling, it would certainly be true to say, like Heraclitus, that we never descend twice in the same river" (233). Wittgenstein, on the other hand, remarked that "The man who said that one cannot step twice into the same river, uttered a falsehood. One can step twice into the same river," while explaining that "what we do is to bring words back from their metaphysical to their normal use in language" ${ }^{39}$ (both Wittgenstein and James are referring to a fragment of Heraclitus which is probably spurious, though since Plato on it is widely accepted as the most famous expression of Heraclitus philosophy). ${ }^{40}$ It is then by an appeal to the "rough ground" (PI: § 107) of ordinary language that the metaphysics implicit in the Heraclitean river is neutralized.

With regard to the feature of continuity, James, often compared to Henri Bergson, ${ }^{41}$ defines the continuous as "that which is without breach, crack or division" (PP: I, 237), and it is in these pages that he proposes to define consciousness as a stream (239). Opposing the traditional psychologists and their empiricist background, James explains that the image of the stream must convey not only the idea of pails or pots of water, but also the fact that "even were the pail and the pots all actually standing in the stream, still between them the free water would continue to flow," because every image in the mind "is steeped and dyed in the free water that flows round it" (255). By acknowledging this, the vagueness that intrinsically characterizes our mental life can be re-instated in its proper place (254). To describe this intrinsic vagueness - which, as Fairbanks (1966: 335 ff.) noted, is a very relevant aspect in Wittgenstein too - James (258) introduces the concept of the fringe, synonyms of which are psychic overtone and suffusion; ${ }^{42}$ images or ideas in the mind do not possess definite contours, but fringed contours, they slowly pass into each other with continuity, and this is due, physiologically, to the "faint brainprocess" that makes us aware of relations and objects only dimly perceived. The examples and explanations that James uses in these pages are, as Wittgenstein underlines in MS 165 , to be connected more easily with spaces than with a stream. Indeed, he speaks for instance about the relation between a thunderclap and the silence which precedes and follows it (240); he compares the life of thought to the flight of a bird with its resting places and places of flight (243); he mentions Zeno's image of the arrow (244); he writes of an "immense horizon" in which "the present image shoots its perspective before us" (256) and of a "halo" that surrounds words and sentences (276). This spatial depiction provides an immediate grasp of the key concept of the continuum, that James will later (in RE) characterize as pure experience. We shall soon return on this aspect, which, as Calcaterra (2010: 207) points out, is strictly connected to James' (and more generally to the pragmatists') anti-dichotomic claims.

29 It must be noticed that James does not use the image of the stream without the awareness of its implications: besides continuity and change, there are also other characteristics which he is interested in highlighting and which this metaphor illustrates with clarity. For example, when discussing attention and effort (I: 451-2) he again turns to his image:

The stream of our thought is like a river. On the whole easy simple flowing predominates in it, the drift of things is with the pull of gravity, and effortless attention is the rule. But at intervals an obstruction, a set-back, a log-jam occurs, stops the current, creates an eddy, and makes things temporarily move the other way. If a real river could feel, it would feel these eddies and set-backs as places of effort.

30 We may wonder why he did not consider banks and stream-beds as equally relevant features, besides currents and eddies. Is it that he simply did not see the role of the banks, 
that is, the role of logic? This would be a hasty conclusion. In fact, in other parts of the PP we can find the description of some elements that, in a sense, force the stream to flow in a certain direction or according to certain rules.

The first connection that it is possible to make is with the chapter on habit, in which the metaphor of a flow of water is used more than once to give account of what happens in the brain, where, due to the plasticity of the nervous tissue, some "currents" shape, through time, paths or channels. ${ }^{43}$ Here, if there is a distinction between brain-matter and what flows through it, James also remarks that what seems fixed is not unchangeable. Paths in the brain can be reshaped, and indeed a relevant part of the chapter is dedicated to the importance of education and training in choosing, strengthen and, in some cases, change the paths. Hence, if there is a distinction between river-beds and waters, change is not the crucial element that discriminates between the two.

To find out something more about this distinction we can turn to the last chapter of the PP, "Necessary truths and the effects of experience." Here we are not dealing with behavioural habits or instincts, but with thought and its laws; nevertheless, again, James' account has to do with the conformation of the brain. The question from which his argument starts, is whether necessary truths, due (as "universally admitted") ${ }^{44}$ to the organic structure of the mind, are explicable by experience or not. In the diatribe between empiricists, who affirm that they are, and apriorists, who affirm that they are not, James defends the apriorists' side, but tries at the same time to give a naturalistic explanation of the cause of these necessary truths. While a single judgment such as that fire burns and water makes wet, or knowledge of time and space relations, may be caused by objects with which we become acquainted, the categories for knowing and judging need to be explained differently (PP: II, 632). It is the Darwinian mechanism of spontaneous variations in the brain that James is thinking of, attributing to it the responsibility of all the kinds of ideal and inward relations among the objects of our thoughts which cannot be interpreted as reproductions of the order of outer experience. Scientific conceptions, aesthetic and ethical systems are due to this category, as well as pure sciences of classification, logic and mathematics, all of which are the result of the fundamental operation of comparison. Comparison "is one of the house-born portions of our mental structure; therefore the pure sciences form a body of propositions with whose genesis experience has nothing to do" (626-7). James connects this theme with that of meaning (a connection which may resemble Wittgenstein's insistence on the difference between the conceptual and the phenomenical), where he, for example, insists that we know the difference between black and white without needing to consult experience: " What I mean by black differs from what I mean by white," and again "what we mean by one plus one is two" because "we are masters of our meanings." 45 Propositions expressing time and space relations - summarizes James (644) - are empirical propositions, those expressing the results of comparison are rational propositions. Yet, why is it that rational propositions turn out to be in agreement with the empirical world? Why is it that the straight line is effectively, every time we need to go from A to B in the real world, the shortest way to connect the two points? "Luckily enough" (658), James answers, we find that the space of our experience is in harmony with our rational suppositions. But we must always remember that necessary truths are ideal relations and that they do not reveal how things really are in the empirical world: they always have to be verified. As he explains in relation to Locke's conception, with which he seems to agree in this respect, such ideas "stand waiting in the mind, forming a beautiful ideal network; and the most 
we can say is that we hope to discover outer realities over which the network may be flung so that ideal and real may coincide" (665).

We might conclude that in James' text there is a precise and clear distinction between empirical and logical levels. Are we to deduce that Wittgenstein's critique is not justified? Things are not as simple as they appear to be. As Myers (1986: 282) points out, in distinguishing necessary truths from empirical facts, James did not mean to abandon a naturalistic conception of science and of psychology as a science. Besides, these ideas are necessarily true merely in a formal sense: it is only when they are confirmed by experience that they can be said to be true in the proper sense; they should be regarded, then, as "empirical hypotheses." ${ }^{46}$ The primacy of the scientific point of view is not dismissed, and the distinction between necessary truths and the effects of experience is made within the scientific, naturalistic framework. ${ }^{47}$

This is not a framework that Wittgenstein could share. In an even more pregnant sense, Wittgenstein's critique of the confusion between the grammatical and the empirical can be read as a critique of the confusion between philosophy and science.

\section{Philosophy and Science}

It is probably also (if not only) ${ }^{48}$ against James' scientific attitude that Wittgenstein's numerous remarks about the importance, in philosophy, to refuse explanation and embrace description, are directed. Indeed, in Manuscripts 130 and 131 (1946, partly published in RPP), which contain a large amount of notes about James' psychology and related themes, Wittgenstein repeatedly argues against causal explanations and hypotheses and in favour of description of linguistic games. ${ }^{49}$

Yet some clarification is needed, in order to gain a more accurate account of James' position. That James, at least at the beginning of his career, meant psychology as scientific, there can be no doubt. As early as 1867 , in a letter to his father, he wrote that what he was thinking about, as his object of study, was "the border ground of physiology and psychology, overlapping both." ${ }^{50}$ In the opening of the PP (I: 5) he clearly affirms that "the psychologist is forced to be something of a nerve-physiologist" and that he has "kept close to the point of view of natural science throughout the book" (Preface: v). But this confidence in science and in the possibility of a scientific psychology later vacillates, and in the Epilogue of the $\mathrm{BC}$, written only two years after the publication of the $\mathrm{PP}$, he confesses that "the natural-science assumptions with which we started are provisional and revisable things" (401), that metaphysics is inevitable because "the only possible path to understand [the relations of the known and the knower] lies through metaphysical subtlety" (399); and, eventually, that "this is no science, it is only the hope of a science." These very words testify, in a sense, that the perspective has not changed: the idea of making psychology a science is still there, though only as a "hope." In the same year (1982), in fact, replying to George T. Ladd's critical review of the PP, he remarked that psychology, in order to be scientific, had to be kept separate from metaphysics ${ }^{51}$ and defended the explanatory point of view. As Perry (1935: II, 119) puts it, "this controversy establishes beyond any doubt the fact that James was looking for a psychology that explained," and particularly that explained scientifically the connections between mind and body. 
the other hand, the impossibility of keeping philosophy and science independent from one another is clear to James, and this is an aspect of the breadth and depth that distinguishes his approach:

The popular notion that 'Science' is forced on the mind ab extra, and that our interests have nothing to do with its constructions, is utterly absurd. The craving to believe that the things of the world belong to kinds which are related by inward rationality together, is the parent of Science as well as of sentimental philosophy; and the original investigator always preserves a healthy sense of how plastic the materials are in his hands. ${ }^{52}$

James did not put science on a pedestal, on the contrary, he often relativized its power and its claims in respects to other modes of knowledge. This attitude parallels his way of conceiving rationality: reason is not separate from feeling, ${ }^{53}$ it springs from feeling, and again the continuum that characterizes human nature supports an anti-dichotomic stance. James' aim, then, can be better described as that of keeping science and philosophy distinct, but not separate. It is this commitment that allows him to hold a naturalistic viewpoint, and at the same time to give space to philosophy and metaphysics, in a fallibilistic and anti-dogmatic spirit ${ }^{54}$ that Wittgenstein probably failed to see.

Goodman (2002: 71) affirms that the later Wittgenstein, too, was moving in James' empiricist direction, in recognizing the contingency of language and in stressing the importance of human natural history, ${ }^{55}$ but that at the same time he preserved the distinction between concepts and experiences, which James did not. Actually, Wittgenstein's alleged empiricism is not so self-evident, particularly in his later writings. Sometimes he had his doubts about natural history itself, and sometimes he even explicitly stated that he did not mean to do natural history. ${ }^{56}$ What is clear, is that he retained James' defense of the contiguity between science and philosophy as heralding conceptual confusion, and James as unconsciously struggling with metaphysics:

Philosophical investigations: conceptual investigations. The essential thing about metaphysics: that the difference between factual and conceptual investigations is not clear to it. A metaphysical question is always in appearance a factual one, although the problem is a conceptual one. ${ }^{57}$

How needed is the work of philosophy is shown by James' psychology. Psychology, he says, is a science, but he discusses almost no scientific questions. His movements, are merely (so many) attempts to extricate himself from the cobwebs of metaphysics in which he is caught. He cannot yet walk, or fly at all, he only wiggles [this sentence is in English in the original text]. Not that that isn't interesting. Only, it is not a scientific activity. ${ }^{58}$

41 Yet James was not so unaware of the metaphysical side of his work, and was not so far from a wittgensteinian perspective when he affirmed that "rightly understood, [metaphysics] means only the search for clearness where common people do not even suspect that there is any lack of it." ${ }^{\prime 59}$ Moreover, he generally considered metaphysics as a vision of the world or a set of beliefs, which could and should be deliberately chosen, primarily because of their practical and ethical consequences. ${ }^{60} \mathrm{~A}$ complete account of the two philosophers' conceptions of metaphysics is, of course, beyond the scope of this paper. It is nonetheless apparent that the different meaning and value that they assign to metaphysics is one of the reasons why it is difficult to compare their attitudes towards the relation between the empirical and the conceptual, science and philosophy.

European Journal of Pragmatism and American Philosophy, IV-2 | 2012 

which often underline James' progressive awareness of the weakness of science and his deepening the metaphysical side of the inquiry. Wilshire (1968: 16) particularly focuses on how James' early project is wrecked because the scientific side of his researches is partly overwhelmed by a sort of protophenomenology; but James' desire to remain faithful to his naturalistic project prevents him from fully developing his phenomenological investigations (202). Now, we may ask, would phenomenology - or radical empiricism meet Wittgenstein's demands? This is doubtful. It is indeed in the overcoming of phenomenology, that Wittgenstein's conception of grammar takes shape in the Thirties, ${ }^{62}$ and this step is never disowned in later years. according to Wittgenstein, is somehow indirect. By describing linguistic games, it guides our attention towards the background that sustains them. The method of perspicuous presentation allows us to perceive the surroundings which define our linguistic practices and the form of life within which they take place. It is here that we reach the bedrock where "the spade is turned," ${ }^{63}$ the subtle but always existing border between rules and moves of the game, or, to get back to our metaphor, the banks and the river-bed of our thoughts. To show these limits, in Wittgenstein's perspective, is no task for any sort of science, nor for any philosophical system as traditionally conceived.

\section{Conclusion}

Our aim was to show the possibility of comparing James' stream of thought and Wittgenstein's river-bed of thoughts and to read the latter as an implicit comment on the former. The analysis of some notes belonging to Wittgenstein's Nachlass has proven that there can be an effective connection between the two images. Wittgenstein's river in an implicit critique of James' stream, and at the same time an insightful interpretation of the virtues of that image, which James himself did not see. This is an example of Wittgenstein's general attitude towards James: he considered some of his intuitions as brilliant, but in the main could not agree with him on the explicit formulation of his ideas. Our inquiry has led us to deepen the analysis of James' characterization of the stream of thought and this, in turn, has widened our investigation to the topic of the relation between science and philosophy. Wittgenstein held that James, in his attempts to be scientific, often lost sight of the richness of his philosophical remarks, and confused the two levels. The metaphor of the river-bed of thoughts, then, in its insistence on the distinction between what is empirical and what is logical, also constitutes a warning against the confusion between science and philosophy. James' own treatment of this matter is, we have argued, more complex than what it appeared to Wittgenstein's eyes. The latter fails to acknowledge the density and the ethical implications of James' approach. Yet, Wittgenstein hits the mark in his underlying that James' characterization of the stream of thought lacks a conceptual vision of the relation between thought and its rules, and of the embeddedness of these rules in the wider context of our form of life with its linguistic practices. A fully pragmatist stance, one could say; save for Wittgenstein's negative attitude towards science, which marks the distance with respects not only to James ${ }^{64}$ but, probably, to pragmatism in general. In any case, this is a topic for a much wider analysis, for which this paper can constitute only a hint.

European Journal of Pragmatism and American Philosophy, IV-2 | 2012 


\section{BIBLIOGRAPHY}

BAILEY A., (1999), "Beyond the Fringe. James on the Transitional Parts of the Stream of Consciousness," Journal of Consciousness Studies, 6 (2-3), 141-53.

BonCoMPAGNi A., (2012a), Wittgenstein. Lo sguardo e il limite, Milano, Mimesis.

BONCOMPAGNi A., (2012b), “'The Mother-Tongue of Thought': James and Wittgenstein on Common Sense," Cognitio - Revista de Filosofia, 13 (2).

CALCATERRA R. M., (2008), "Truth in Progress: The Value of the Facts-and-Feelings Connection in William James," in Flamm M. C., Lachs J. \& Skowroñski K. P., (ed.), American and European Values: Contemporary Philosophical Perspectives, Newcastle-upon-Tyne, Cambridge Scholars Press.

CALCATERRA R. M., (2010), "Mente e natura tra metafisica ed epistemologia," in Bufalo R., Cantarano G. \& Colonnello P., (ed.), Natura storia società. Saggi in onore di Mario Alcaro, MilanoUdine, Mimesis.

CHAUVIRÉ C., (2003), Voire le visible: la seconde philosophie de Wittgenstein, Paris, Presses Universitaires de France.

Coliva A., (2010), Moore and Wittgenstein. Skepticism, Certainty and Common Sense, Basingstoke, Macmillan.

CROSBY D. A. \& W. VINEY, (1995), “Toward a Psychology that is Radically Empirical: Recapturing the Vision of William James," in Donnelly M. E. (ed.), Reinterpreting the Legacy of William James, Washington DC, American Psychological Association.

EDIE J., (1987), William James and Phenomenology, Bloomington, Indiana University Press.

EGIDI R., (1995), “Wittgenstein between Philosophical Grammar and Psychology,” in Egidi R., (ed.), Wittgenstein: Mind and Language, Dordrecht, Kluwer Academic Publishers.

FAIRBANKS M., (1966), “Wittgenstein and James,” The New Scholasticism, XL (3).

flanagan O., (1997), "Consciousness as a Pragmatist Views It," in Putnam R. A., (ed.), The Cambridge Companion to William James, Cambridge, Cambridge University Press.

GALE R. M., (1999), The Divided Self of William James, Cambridge, Cambridge University Press. GIORGI A., (1990), "The Implications of James' Plea for Psychology as a Natural Science," in Johnson M. G. \& Henley T. B., (eds.), Reflections on the Principles of Psychology, Hillsdale, NJ, Lawrence Erlbaum Associates.

Goodman R., (2002), Wittgenstein and William James, Cambridge, Cambridge University Press.

HACKER P. M. S., (1990), Wittgenstein. Meaning and Mind (An Analytical Commentary on the PI, vol. 3), Oxford, Blackwell.

HACKER P. M. S., (1996), Wittgenstein. Mind and Will (An Analytical Commentary on the PI, vol. 4), Oxford, Blackwell.

HILMY S. S., (1987), The Later Wittgenstein, Oxford, Blackwell. 
JACKMAN H., (2004), “Wittgenstein \& James' Stream of Thought," Saap 2004 Annual Meeting, [ ytorku.ca/hjackman/papers/WittJames.pdf].

JAMES W., (1884), “On Some Omissions of Introspective Psychology,” Mind, 9 (33).

JAMES W., (1890), The Principles of Psychology (PP), New York, Holt.

JAMES W., (1892/1984), Psychology: Briefer Course (BC), Cambridge MA, Harvard University Press.

JAMES W., (1897), The Will to Believe and other Essays in Popular Philosophy, New York, Longmans, Green and Co.

JAMES W., (1907) Pragmatism (P), New York, Longmans, Green and Co.

JAMES W., (1912), Essays in Radical Empiricism (RE), New York, Longmans, Green and Co.

MYERS G. E., (1986), William James. His life and Character, New Haven, Yale University Press.

MONK R., (1991), Wittgenstein. The Duty of Genius, London, Vintage.

MOORE G. E., (1925/1959a), “A Defense of Common Sense,” in Philosophical Papers, 1959, New York, Macmillan.

MOORE G. E., (1939/1959b), "Proof of an External World," in Philosophical Papers, 1959, New York, Macmillan.

MOYAL-SHARROCK D., (2003), “Logic in Action: Wittgenstein's Logical Pragmatism and the Impotence of Skepticism," Philosophical Investigations, XXVI.

MOYAL-SHARROCK D., (2007), Understanding Wittgenstein's On Certainty, Basingstoke, Macmillan. NUBiola J., (2000), “Ludwig Wittgenstein and William James," Streams of William James, 2 (3). PASSMORE J., (1966), A Hundred Years of Philosophy, London, Duckworth. PERISSINOTTO L., (1991), Logica e immagine del mondo. Studio su Über Gewissheit, Milano, Guerini. PERRY R. B., (1935), The Thought and Character of William James, Boston, Little, Brown and Co. (2vv.). PERRY R. B., (1958), In the Spirit of William James, Bloomington, Indiana University Press. sChUETZ A., (1941), “William James' Concept of the Stream of Thought Phenomenologically Interpreted," Philosophy and Phenomenological Research, 1 (4).

schulte J., (1995), “Emotions: Remarks on Wittgenstein and William James,” in Egidi R., (ed.), Wittgenstein: Mind and Language, Dordrecht, Kluwer Academic Publishers.

SHINER R. A., (1974) “Wittgenstein and Heraclitus: Two River-Images,” Philosophy, 49.

STEINER P., (2012), "Une question du point de vue. James, Husserl, Wittgenstein et le sophisme du psychologue," Revue Internationale de Philosophie, 1 (259).

STERN D. G., (1991), “Heraclitus and Wittgenstein's River Images: Stepping Twice Into the Same River," The Monist, 74 (4).

STROLL A., (1994), Moore and Wittgenstein on Certainty, Oxford, Oxford University Press.

TER HARK M., (2004), “'Patterns of Life': a Third Wittgenstein Concept,” in Moyal Sharrock D., (ed.), The Third Wittgenstein: The Post-Investigations Works, Adershot, Ashgate.

WERTZ S. K., (1972), “On Wittgenstein and James,” The New Scholasticism, XLVI (4).

WILSHIRE B., (1968), William James and Phenomenology: a Study of 'The Principles of Psychology,' Bloomington, Indiana University Press. 
WITTGENSTEIN L., (1967), Zettel, Oxford, Blackwell.

WitTGENSTEIN L., (1969), On Certainty (OC), Oxford, Blackwell.

WITTGENSTEIN L., (1974), Letters to Russell, Keynes and Moore, edited by G. H. von Wright, Oxford, Blackwell.

WITTGENSTEIn L., (1975), Philosophical Remarks (PR), Oxford, Blackwell.

WITTGENSTEIN L., (1977), Remarks on Colour (RC), Oxford, Blackwell.

WITTGENSTEIN L., (1980), Remarks on the Philosophy of Psychology (RPP), Oxford, Blackwell.

WitTGENSTEIn L., (1981), Personal Recollections, edited by R. Rhees, Oxford, Blackwell.

WITTGENSTEIN L., (1988), Wittgenstein's Lectures on Philosophical Psychology, edited by P. T. Geach, Brighton, Harvester.

WitTGENSTEIN L., (2000), Wittgenstein's Nachlass. The Bergen Electronic Edition (BEE), Oxford, Oxford University Press.

WITTGENSTEIN L., (2001), Philosophical Investigations (PI), Oxford, Blackwell.

\section{NOTES}

1. Wittgenstein (1974: 10, 82).

2. Wittgenstein (1981: 121).

3. Hereafter, I will mention James' and Wittgenstein's major works by initials; see the bibliography for details.

4. Goodman (2002: 17).

5. Monk (1991: 477).

6. Wittgenstein 1988 .

7. Ter Hark (2004: 131, 137), Goodman (2002: 113), Schulte 1995.

8. Passmore (1966: 434), Fairbanks 1966, Wertz 1972.

9. Particularly in Hacker (1990: ch. 2), Hacker (1996: ch. 4, 5, 6); cf. also Hilmy (1987: ch. 4, 6) and Gale (1999: 165).

10. Hacker (1990: 305).

11. Nubiola 2000, Goodman (2002: 63 ff.), Jackman 2004.

12. Wittgenstein (1981: 121).

13. Steiner 2012 is an interesting exception.

14. PR: §§ 52-5, 88, 213.

15. RPP: II, §§ 415, 504; PI: part II, 184.

16. Cf. also Boncompagni (2012a: 47, 154).

17. I'm citing 165 before 129 because 165 precedes 129 chronologically.

18. BEE, Items 114, 212, 302.

19. BEE, Item 176.

20. Hacker (1996: 476) affirms that Wittgenstein comments on James' conception of the stream of thought only in Manuscripts 124 and 129, and that in both cases he accuses him of conflating a priori and a posteriori; as we shall see, there are a few more occasions in which James' stream is cited and a more complete analysis can show that it was not only with a critical eye that he looked at this image.

21. "Ist der Gedankenstrom unterbrochen, so können wir nur vermuten, wie er weitergelaufen wäre" (BEE: Item 120, 97r). I transcribe the original German version only for those parts of the 
manuscripts which strictly relate to the stream of thought. Translations from the Nachlass are mine, unless differently specified.

22. "Hier könnte vom Gedankenstrom, von dem James redet, gesprochen werden und man könnte darauf hinweisen daß, so wie einmir wohlbekannter Name genannt wird, meine Gedanken sich gleich in eine Reihe von Kanäle ergießen und in ihnen weiterlaufen und daß die Bedeutung des Namens sich in diesen Strömen offenbart" (BEE: Item 124, 235).

23. "Ich erwarte zwei Leute A und B. Ich sage: "Wenn er doch nur käme!” Jemand fragt mich. "Wen meist Du?" Ich sage, "Ich habe an den A gedacht." Und diese Worte selber haben eine Brücke hergestellt. Oder er fragt "Wen meinst Du" und ich antworte: "Ich habe an... gedacht," ein Gedicht in dem dieser Satz vorkommt. Die Verbindungen dessen was ich sage mache ich im Laufe meiner Gedanken und Handlungen. (Diese Betrachtung hängt mit dem zusammen was W. James "the stream of thought nennt." Den Fehler in seiner Darstellung ist daß a priori und a posteriori grammatisches und erfahrungsgemäßes durcheinander nicht unterschieden werden So redet er von der Kontinuität des Gedankestroms und vergleicht sie mit der des Raums, nicht mit der eines Wasserstrahles etwa.)" (BEE, Item 165: 24-5).

24. "(Ich glaube, diese Betrachtung hängt mit dem zusammen, was W. James "the stream of thought" nennt. Wenn er freilich auch a priori und a posteriori, Erfahrungssätze und grammatische, nicht unterschiedet)" (BEE: Item 129, 107).

25. "Man könnte sagen: Ich hätte keinen Eindruck von dem Zimmer als ganzes, könnte ich nicht meinen Blick schnell in ihm dahin und dorthin schweifen lassen und mich nicht frei in ihm herumbewegen. (Stream of thought) James" (BEE, Item 129: 114).

26. Goodman (2002: ch. 5).

27. Goodman (2002: 106), Gale (1999: 165).

28. Boncompagni (2012a: 106).

29. RPP: II, § 504; Steiner 2012. James will also speak of the flux of life in subsequent writings (see for example RE: 93). The context is evidently different, but there are also some similarities. On the continuity of James' thought between the two works, see Crosby \& Viney 1992; on the discontinuity, Myers (1986: 78-80).

30. This paragraph, if read together with James' characterization of psychology in the Epilogue of the $\mathrm{BC}$, really sounds like a comment on James' words. Wittgenstein indeed says that "the confusion and barrenness of psychology is not to be explained by calling it a 'young science'; its state is not comparable with that of physics, for instance in its beginnings" (PI: part II, 197); and James had written that "at present psychology is in the condition of physics before Galileo and the laws of motion, of chemistry before Lavoisier and the notion that mass is preserved in all reactions" (BC: 401).

31. Wittgenstein (1988: 245; see also 92 and 205; and RPP: I, §§ 46, 173, 549; II §§ 214, 264, 321).

32. "I am inclined to believe that not everything that has the form of an empirical proposition is one": OC $\S 308$ (emphasis in the original). Cf. also §§ 136, 319, 321, 401-2, 494, 569.

33. In Moore 1959b, originally published in 1939. Cf. OC: $\S 1$. Wittgenstein's remarks also refer to Moore 1959a, originally published in 1925.

34. Moyal-Sharrock 2003.

35. In this distinction Stroll (1994: ch.9) grounds what he calls Wittgenstein's "heterogonous foundationalism": certainty can constitute a foundation for knowledge because it is not part of knowledge.

36. James' account of common sense ( $\mathrm{P}$ : Lecture V), though presenting some affinities with Wittgenstein's approach, is much more similar to Moore's, particularly in considering common sense as a set of pieces of knowledge. Cf. Boncompagni 2012b.

37. Cf. Perissinotto (1991: $173 \mathrm{ff}$.).

38. There are many remarks on this in OC, the most striking of which is $\S 286$. 
39. BEE: Item 110, 34; see also pp. 39 and 155, and Items 116: 226; 120: 50v; 142: 116. The proposition about metaphysics appears also in PI: I, § 116.

40. Interestingly, the previous formulation of James' remark, contained in James (1884), is more attuned with what critics consider the "true" Heraclitus, who spoke about a river which remains the same with water which flows and changes; James (1884: 11) indeed stated that "of the mental river the saying of Herakleitos is probably literally true: we never bath twice in the same water there." On the interpretations of Heraclitus and the connected images of the river in Wittgenstein, see Shiner 1974 and Stern 1991. Unfortunately none of the two acknowledges the importance that James' image may have had on Wittgenstein's account.

41. Passmore (1966: 105 ff.). On the relation between the two thinkers see Perry (1935: II, ch. LXXXVI)

42. Cf. Bailey (1999: 145).

43. PP: I, 106, 107, 113.

44. PP: II, 617.

45. Respectively p. 644 and 655 (emphasis in the original). On James' different conceptions of meaning in the PP and in other writings, cf. Myers (1986: 285).

46. Crosby \& Viney (1992: 111).

47. For a non naturalistic account, see Flanagan 1997.

48. Hilmy (1987: 207).

49. BEE: Item 130, 35, 71-2 (RPP: I, 46), 218; Item 131, 56 (RPP: I, 257).

50. Perry (1935: I, 254).

51. Giorgi (1990: $69 \mathrm{ff}$.).

52. PP: II, 667.

53. Cf. The Sentiment of Rationality, in James (1897: ch. 3).

54. Calcaterra (2008: 94 ff.).

55. PI: part I, § 415.

56. RPP: I, § 46; PI: part II, § XII; RC: part III, § 9.

57. RPP: I, § 949 (originally in MS 134: 153).

58. This remarks comes from the same Manuscript 165 (p. 150-1) in which is our first "stream with no banks" occurrence. I am using, here, Hilmly's (1987: 196-7) translation.

59. In a letter dated 1888 to the positivist psychologist Ribot, cited in Edie (1987: ix) and in Perry (1958: 58).

60. For example in James (1897: ch. 1).

61. Schuezt 1941, Wilshire 1968, Edie 1987.

62. Cf. Egidi (1995: 174) and Chauviré (2003: 20).

63. PI: § 217 .

64. Goodman (2002: 30 ) too considers the attitude towards science as one of the big differences between the two thinkers.

\section{ABSTRACTS}

The influence of William James on Ludwig Wittgenstein has been widely studied, as well as the criticism that the latter addresses to the former, but one aspect that has only rarely been focused on is the two philosophers' use of the image of the flux, stream, or river. The analysis of some 
notes belonging to Wittgenstein's Nachlass support the possibility of a comparison between James' stream of thought, as outlined in the Principles of Psychology, and Wittgenstein's river-bed of thoughts, presented in On Certainty. After an introduction which offers a general frame for the following work, the first section of the paper examines all the Nachlass entries that directly mention James' stream. Section 2 focuses on two remarks in which Wittgenstein explicitly criticizes James' concept and implicitly anticipates his own way of dealing with this matter. These remarks, belonging to Manuscripts 165 and 129, both dating 1944, have not been published in any of Wittgenstein's edited books, nor is it possible to find the same argument elsewhere. Wittgenstein's critique concerns James' lack of distinction between what is grammatical, or a priori, and what is empirical, or a posteriori, a distinction which the image of the stream should have suggested: a stream flows in a stream-bed and within banks. This is exactly the meaning that Wittgenstein's own metaphor of the river-bed of thoughts is intended to convey. Section 3 analyses James' concept of the stream and its corollaries, in order to clarify whether Wittgenstein's critique is justified or not. James in effect draws a separation between a priori and a posteriori, but this separation is conceived from within the framework of empirical science. This analysis leads to the theme of the relations among science, philosophy and metaphysics, which is the subject of section 4 . The conclusion is that Wittgenstein did appreciate James for his intuitions and for the power of his imagination: in a sense he even developed them; but he could not agree on the explicit formulation of his ideas.

\section{AUTHOR}

\section{ANNA BOCOMPAGNI}

Università di Roma Tre

anna.boncompagni[at]uniroma3.it 